\title{
The Effect of Foreign Direct Investment and Economic Freedom on Economic Growth: The Case of BRICS Countries
}

\author{
Ceyhun Haydaroğlu ${ }^{1}$ \\ ${ }^{1}$ Department of Economics, Faculty of Economics and Administrative Sciences, Bilecik Şeyh Edebali University, \\ Bilecik, Turkey \\ Correspondence: Ceyhun Haydaroğlu, Department of Economics, Faculty of Economics and Administrative \\ Sciences, Bilecik Şeyh Edebali University, Bilecik, Turkey.
}

Received: January 4, 2016

Accepted: February 15, 2016

Online Published: March 7, 2016

doi:10.5430/rwe.v7n1p1

URL: http://dx.doi.org/10.5430/rwe.v7n1p1

\begin{abstract}
This paper researches the interaction between economic freedom (EF), foreign direct investment (FDI) and economic growth in the five BRICS countries namely, Brazil, Russia, India, China and South Africa over the term 1995-2013. In order to trying the data, panel data analysis is exercised. The results indicate that whole index of EF is positively and acutely associated with economic growth, further, the results indicate that FDI is positively related and statistically significant determinant of economic growth. We find that EF and FDI has significant influence on economic growth. Besides, we decompose the EF index into the five categories constructing the index and observed that just index of size of government is negatively associated with growth.
\end{abstract}

Keywords: economic freedom, foreign direct investment, economic growth, BRICS

\section{Introduction}

BRICS is an association of five major emerging economies Brazil, Russia, India, China and South Africa was coined by Jim O'Neill in 2001. The group was initially known as BRIC before the attendance of South Africa in 2010. All members are newly industrialized countries but they are distinguished by their extensive, fast-growing economies and significant affect on regional and worldwide affairs. Taken as a transcontinental group the BRICS countries do matter in the way of population, land surface, and economies their sizes are effective (van Agtamael, 2012). The BRICS turned out to be an important aspect of the contemporary globalized era and what distinguishes them from any other story of emerging markets growth is their ability to affect and to be affected by the global economy (O’Neill, et. al. 2005).

The global economy has experienced incomparable paradigm shifts in the last decade. Coupled with the recent crises in developed regions, it may be just at the right time for emerging economies to fill the gap of growth left vacant by developed countries in order to drive global economic performance. Despite decades of civil unrest, political and economic turmoil shading some of these countries, there are strong symptoms that economic performance is fast growing in these regions. Although still impotent to free themselves from the shackles of corruption and poverty, the success of these economies currently rests on their ability to attract FDI from developed and developing countries.

Generally, it seems important to emphasize, first, that the findings with respect to developing economies specify that FDI has a positive impact on economic growth (Campos and Kinoshita, 2002; Johnson, 2006), which is consistent with the theoretical premise that FDI increases the technological upgrading of and knowledge spillovers within technologically inferior recipient economies. Second, there is extreme evidence suggesting that the scope to which FDI enhances growth on the whole depends on the absorptive capability of the recipient economy, which points to the significance of complex, country determined features that allow for extracting benefits from FDI (Borenzstein et. al. 1998; Fortanier 2007). Third, the empirical evidence generally supports the hypothesis that FDI exerts a positive effect on economic growth according to the degree of complementarily and replacement between FDI and domestic investments (Chang, 2010; de Mello, 1999).

The studies investigating the linkage between EF and economic growth found a positive effect of various measures of EF on economic growth (Ali and Crain, 2002; Dawson, 1998; De Haan and Siermann, 1998; De Haan and Sturm, 2000; Heckelman and Stroup, 2000). Note that the concept globalization is very near to the concept of EF, studies 
find that globalization increases economic growth. However, depth of EF can have a negative impact, especially for developing economies (Cole, 2003). In this context, Gray (2000) pointed out that the essential mechanisms through which globalization influences development is through greater openness of international trade, greater mobility of financial assets and greater ease of the transfer of bundles of resources through FDI by multinational firms.

Bengoa and Sanchez-Robles (2002) explored the interaction between EF, FDI and economic growth using panel data analysis for a sample of 18 Latin American countries. The purpose of this paper is to extend the empirical framework of Bengoa and Sanchez-Robles (2002) to cover the relationship between EF, FDI and economic growth in fast emerging BRICS countries. The set of fast emerging countries included in the research are Brazil, Russia, India, China, South Africa. The rest of the paper is structured as follows. Section 2 contains a succinct review of the literature and empirical evidence on the FDI, EF and growth linkage. Section 3 describes the empirical model, dataset and methodology. The results are presented and discussed in section 4 . The sixth and final section succinctly concludes.

\section{Literature Framework and Empirical Evidence}

The traditional economic theory suggests that dependence to EF should ease more FDI inflows into target countries as it reduces ineffectualities, deadweight losses and uncertainties (Voyer and Beamish, 2004). The lack of EF can be symptomatic of the various ways in which a government may take away potential profits and can be an obstacle to FDI (Conklin, 2002). Restraining trade policies, for example, may discourage multinational corporations by restriction their ability to import required inputs and increasing their transaction costs, thus lowering productive efficiency (Harms and Ursprung 2002, Drabek and Payne 2002, Habib and Zurawicki 2002). Similarly, some EF variables in source countries such as financial, trade and business freedom which involve freedom to operate internationally are likely to facilitate more FDI outflows.

Quality of institutions and, by implication, the level of economic freedom, can affect both availability and productivity of human and capital resources and might play an impressive role in its economic development. EF is a condition or state of being in which individuals can act with autonomy while in the chase of subsistence. It therefore implies that the right to produce, trade and consume any goods and services is almost a fundamental right for one and all. North (1990) pointed out that a society's institutional framework can play a crucial role in the long-term performance of its economy. Mauro (1995) observed that corruption obstructs economic growth. Moreover, secure property rights can attract outside capital, make access to credit easier, lower interest rates, innovation, maintenance of property and economic growth.

There is more cause to anticipate a steady relationship between changes in EF and growth. Reliability, however, is vitally important here. Because reliability must be earned, there will often be a time lag between a change in EF and when the change exerts an effect on economic output. Both historical factors and current political conditions will affect the length of time required to earn reliability. Thus, the time period between when there is a change in policy that influences EF and its impact on the growth of output is likely to vary, and in some cases it may be quite lengthy. The success among East Asian economies were explained by the overcoming of utilizing FDI to improve economic growth, resulting from their export-promotion strategy, improving education and human capital, policies that encourage export-oriented FDI, adopting trade liberalization and macroeconomic stability (Ahmed and Anoruo, 2000). It was illustrated that FDI to growth causality was underpinned by capital stock propensities, greater trade openness, restricted rule of law and lower income level while greater political rights and restricted rule of law were the major factors that explained growth to FDI causality (Dhakal et. al., 2007).

There is also new flow of economic literature that attempts to clarify conflicting results of the FDI growth linkages across the countries with the differences in the level of EF. There are number of studies that attempt to show from where comes the difference and what factors become crucial for investors while making the decision to invest money abroad. The general argument of this new literature is that investors' decision to invest in a foreign country is very much connected with the economic situation inside the country and the state of the institutional environment. Thus including the various measurements of EF could help to estimate the real effects of FDI on growth rates. Usually such kinds of studies use already constructed special indices which represent the combination of different components defining the various qualities of countries institutions.

Jadhav (2012) investigated the role of economic, institutional, and political factors in attracting FDI to BRICS economy. The findings of the research state that market size, openness to trade, and rule of law play important roles in attracting FDI to BRICS while natural resource availability had a negative effect, implying that FDI to BRICS is largely market-oriented. Jadhav and Katti (2012), observed that governance efficiency and regulatory quality had a positive impact on FDI inflow in BRICS while political instability, voice and accountability, and control of 
corruption had negative effects. Vijayakumar et al. (2010), employed panel analysis to examine the determinants of FDI to BRICS and observed that market size, labor cost, infrastructure, and gross capital formation contributed positively while trade openness and inflation were insignificant.

Pearson et. al. (2012) examined the relationship between economic freedom, state growth and FDI in a panel of the 50 states in America. The research found both EF and growth rate to each state to have positively and significantly affected the inflow of FDI. Chong and Calderón (2000) empirically found that improvements in the institutional framework have a positive effect on growth. Dawson (1998), Ayal and Karras (1998), De Haan and Sturm (2003), and Carlsson and Lundstrom (2002) investigated the relations between various components of freedom and growth and observed that some of them were associated with growth while some of them were not.

Gwartney (2009) reveals that countries with more EF have higher shares of private investment in GDP, higher productivity of private investment, grow more rapidly and achieve higher levels of per capita income than countries with lower levels of EF. Heckelman (2000) observed that the average level of freedom precedes growth whereas growth may precede one of the components government intervention; he did not find any relationship between growth and two of the indexes that are deemed to be components of EF trade policy and taxation. Vega-Gordillo and Alvarez-Arce (2003) found that EF fosters economic growth. Dawson (2003) found that the level of overall EF, and most of its underlying components, are Granger-caused by the level of political and individual liberties. Justesen (2008) finds that some aspects of EF influence growth and investment. Thus, there is only weak evidence that growth affects EF.

Janicki and Wunnava (2004) found important role of economic growth, political risk, trade openness and labor cost to explain the flow of FDI to Central and Eastern European countries. Kyrkilis and Pantelidis (2003) examined the determinants of FDI in developing and developed countries and discovered that real GNP, effective exchange rate, and human capital were important determinants of FDI flows. Mahmood et al., (2010) researched the link between $\mathrm{EF}$ and economic growth. They found that size of government has negative correlation with growth, whereas financial, trade, investment, business, property rights, and freedom from corruption have positive relation with growth. Hanke and Walters (1997) reported that it was found a positive relationship between EF and the GDP per capita. Cebula (2011) investigates the effect of the EF on economic growth in the OECD countries and concludes that economic growth is positively correlated with monetary, business, investment, labor, fiscal, property rights, and freedom from corruption. Islam (1996) showed that EF has a direct relation with per capita income and economic growth for 98 low, middle, and high income countries.

Carlsson and Lundstrom (2002) found that some of the categories in the EF are insignificant and some of the significant variables negatively related with increases in economic growth. As well as empirical evidence subject to the relation of EF and economic growth, theoretical studies confirm the existence of this relationship. North (1990), institutions have the incentive role in the economy by encouraging the production to increase and supporting valuable national output. Berggren (2003), the countries with an independent legal system, protective property rights, full capital mobility, have advantages such as productivity in goods and services through low taxation, and capital investment, and the highest returns. Pradhan (2009) research the determinant of FDI in BRICS countries over the period 1980 to 2010. Zafar (2013) examines the impact of a variety of factors market size, trade openness and cost of capital among others on FDI inflows into India, Pakistan and Bangladesh. These both studies conclude that there is a strong and positive relationship between FDI flows and economic growth in these countries. Broadman and Recanatini (2001) analyzed market size, education level, local investment, cost of labour, transportation and infrastructure variables to explain the regional and total FDI in Russia. They have significant impact on FDI.

Among the adherents that tilted along institutional lines of reasoning are Knack and Keefer (1995), Demetriades and Law (2006) and Rodrik, Subramanian, and Trebbi (2004). They extolled the virtues of institutional factor as an important growth recipe more than any other conditioning variables. Largely, the strand of literature that creates a role for EF in FDI-growth relation is undoubtedly scarce or at best rudimentary. Bengoa and Sanchez-Robles (2003) explored the interplay between EF, FDI and economic growth using panel data for a sample of 18 Latin American countries over the period spanning 1970 through 1999. Their results suggest that FDI is positively correlated with economic growth. Azman-Saini, Baharumshah, and Law (2010) also investigated the systemic link between EF, FDI and economic growth. The results, reveal that FDI by itself has no direct positive effect on output growth. Instead, the effect of FDI is contingent on the level of EF in the host countries. This means the countries promote greater freedom of economic activities gain significantly from the presence of multinational corporations.

Tiwari (2011) examined the effectiveness of foreign aid, FDI, and EF for selected 28 Asian countries. The model includes foreign aid, FDI, EF, labour force, and capital stock. The results indicated that an increase in the fiscal 
freedom, financial freedom and domestic capital stock were significant factors positively affecting economic growth. Freedom from corruption, inflow of FDI and foreign aid were significant factors negatively affecting economic growth. Further, they found that life expectancy played a significant and positive role in economic growth.

\section{Model Specification, Data Description and Econometric Methodology}

We employ various control variables that may influence growth and we forecast equation with the whole index of EF and FDI. We solve the EF into all genres building the index. Descriptive statistics of variables in the research are illustrated in Table 1.

Table 1. Descriptive statistics of variables in the research

\begin{tabular}{cccccc}
\hline Variable & Observations & Mean & Std. Deviation & Min & Max \\
\hline GDP & 90 & 11.95 & 0.78 & 11.27 & 12.97 \\
\hline EF & 92 & 62.17 & 7.77 & 37.45 & 79.05 \\
\hline EF1 & 92 & 1.56 & 0.72 & 0.96 & 2.28 \\
\hline EF2 & 92 & 0.98 & 0.66 & 0.64 & 1.28 \\
\hline EF3 & 92 & 1.24 & 0.87 & 0.62 & 1.63 \\
\hline EF4 & 92 & 0.92 & 0.39 & 0.49 & 1.23 \\
\hline EF5 & 92 & 0.84 & 0.28 & 0.32 & 1.04 \\
\hline FDI & 94 & 9.56 & 1.41 & 5.21 & 11.16 \\
\hline TROPEN & 92 & 36.07 & 19.92 & 13.54 & 112.04 \\
\hline INF & 90 & 104.72 & 7.17 & 94.32 & 146.46 \\
\hline GCF & 94 & 25.28 & 9.08 & 15.18 & 45.65 \\
\hline FINDEP & 90 & 83.52 & 20.23 & 45.96 & 127.21 \\
\hline
\end{tabular}

We pursue the available literature on EF, FDI and economic growth in excerpting our variables (Dawson 1998, Gwartney et al., 2004) and with tracing Ray (1989), Bengoa and Sanchez-Robles (2003), Kapuria-Foreman (2007), Dollar and Kraay (2002) Romalis (2007).

To investigate the links between EF, FDI and economic growth we follow a panel data analysis. Equation is as tracing:

$$
\log (\mathrm{GDP})_{\mathrm{it}-1}=\beta_{0}+\beta_{1} \mathrm{EF}_{\mathrm{it}-1}+\beta_{2} \mathrm{FDI}_{\mathrm{it}-1}+\varepsilon_{\mathrm{it}-1}
$$

The variables used in first equation estimation are: (GDP) is the natural log of the per capita GDP in constant 2000 US\$ that is the agent variable of economic growth; EF is rating of EF that is calculated from five EF indexes (business, trade, government size, monetary, and property right); FDI is FDI in current US\$ for country.

$$
\begin{aligned}
\log (\mathrm{GDP})_{\mathrm{it}-1}=\beta_{0}+\beta_{1} \log (\mathrm{EF})_{\mathrm{it}-1} & +\beta_{2} \log (\mathrm{FDI})_{\mathrm{it}-1}+\beta_{3} \log (\mathrm{EF} 1)_{\mathrm{it}-1}+\beta_{4} \log (\mathrm{EF} 2)_{\mathrm{it}-1}+\beta_{5} \log (\mathrm{EF} 3)_{\mathrm{it}-1} \\
& +\beta_{6} \log (\mathrm{EF} 4)_{\mathrm{it}-1}+\beta_{7} \log (\mathrm{EF} 5)_{\mathrm{it}-1}+\varepsilon_{\mathrm{it}-1}
\end{aligned}
$$

Exclusive of equation 1, EF1: refers to the value of government size, EF2: refers to the value of property rights, EF3: refers to the value of monetary freedom, EF4: refers to the value of trade freedom and EF5: refers to the value of business freedom in equation 2 .

$$
\begin{aligned}
& \log (\mathrm{GDP})_{\mathrm{it}-1}=\beta_{0}+\beta_{1} \log (\mathrm{EF})_{\mathrm{it}-1}+\beta_{2} \log (\mathrm{FDI})_{\mathrm{it}-1}+\beta_{3} \log (\mathrm{EF} 1)_{\mathrm{it}-1}+\beta_{4} \log (\mathrm{EF} 2)_{\mathrm{it}-1}+\beta_{5} \log (\mathrm{EF} 3)_{\mathrm{it}-1}+\beta_{6} \log (\mathrm{EF} 4)_{\mathrm{it}-1} \\
& \quad+\beta_{7} \log (\mathrm{EF} 5)_{\mathrm{it}-1}+\beta_{8} \log (\mathrm{TROPEN})_{\mathrm{it}-1}+\beta_{9} \log (\mathrm{FINDEP})_{\mathrm{it}-1}+\beta_{10} \log (\mathrm{INF})_{\mathrm{it}-1}+\beta_{11} \log (\mathrm{GCF})_{\mathrm{it}-1}+\varepsilon_{\mathrm{it}-1}
\end{aligned}
$$

Exclusive of equation 2, FDI: total foreign direct investment, TROPEN: Trade Openness is estimated as ratio of import of goods and services plus export of goods and services divided by GDP, FINDEP: financial development indicator measured by broad money supply over GDP, INF: infrastructure quality log per capita electricity, GCF: gross capital formation to the percent of GDP in equation 3.

We first estimated equation without control variables for show the main relationship between growth, FDI, EF and major variables for BRICS in 1995-2013. Annual data from 1995 to 2013 for Brazil, Russia, China, India, South 
Africa are from IMF International Financial Statistics and Department of Statistics and Central Bank of each country. EF is from the Heritage Foundation.

The Panel data model includes three different techniques: Common constant, Fixed effects, Random effects. The research estimates all these three techniques so as to incorporate the best fit of the estimation. Generally in the panel data analysis, the Fixed effects model assumes that each country differs in its intercept term, whereas the Random effects model assumes that each country differs in its error term. However, the Hausman specification test (1978) guides us to choose the appropriate Panel data model either Fixed effects method or Random effects model.

\section{Empirical Results and Discussion}

This section introduces the empirical results of the estimation. I will provide the explanation of all the findings of this research and will make comparison of my results with the results of the previous literature on the topic. In this research, we used the methods of Im et al., (IPS) (2003), Augmented Dickey Fuller Fisher, Phillips-Perron Fisher, Levin, Lin and Chu (LLC) (2002) as the panel unit root tests. Both Augmented Dickey-Fuller (ADF) and Kwiatkowski-Phillips-Schmidt-Shin (KPSS) unit root tests for individual countries as well as panel unit root tests are applied in order to check for robustness of the time series. All the macroeconomic fundamental and country specific time series are transformed to ensure there is no unit-root problem and that all the time series used in the tests are stationary. Panel unit root test results are shown in Table 2.

Table 2. Panel Unit Root Test results

\begin{tabular}{|c|c|c|c|c|}
\hline & LLC $t^{*}$ & IPS W-stat & ADF Chisquare & PP Chisquare \\
\hline GDP & $-6.35^{*}$ & $-4.87 *$ & $47.94 *$ & $63.08^{*}$ \\
\hline FDI & 590.96 & $-7.24 *$ & $70.81^{*}$ & 101.34* \\
\hline $\mathbf{E F}$ & $-18.70^{*}$ & $-13.02^{*}$ & $219.43^{*}$ & $252.45^{*}$ \\
\hline TROPEN & $-6.55^{*}$ & $-6.56^{*}$ & $51.26^{*}$ & $86.06^{*}$ \\
\hline FINDEP & $-6.44 *$ & $-4.97 *$ & $51.55^{*}$ & $85.58 *$ \\
\hline GCF & $-4.20 *$ & $-7.68 *$ & $72.54 *$ & $119.87^{*}$ \\
\hline INF & $-31.61^{*}$ & $-15.78^{*}$ & $48.27^{*}$ & $96.41 *$ \\
\hline EF1 & $-17.34^{*}$ & $-13.65^{*}$ & $239.41^{*}$ & $317.28^{*}$ \\
\hline EF2 & $-8.63^{*}$ & $-6.82^{*}$ & $63.74^{*}$ & $65.65^{*}$ \\
\hline EF3 & $-15.96^{*}$ & $-10.88^{*}$ & $186.53^{*}$ & $241.34^{*}$ \\
\hline EF4 & $-24.02^{*}$ & $-17.82^{*}$ & $289.14^{*}$ & $383.56^{*}$ \\
\hline EF5 & $-16.42^{*}$ & $-12.51^{*}$ & $208.52^{*}$ & $221.38^{*}$ \\
\hline
\end{tabular}

Note: LLC, IPS and ADF and PP-Fisher tests have null hypothesis of the existence of a unit root in any of the series in the panel. $*, * *$ and $* * *$ denote statistical significance at 1,5 and $10 \%$.

In order to selecting the best methods, Pooled Least Squares (PLS), fixed effects (FE) and random effects (RE), we used testes of F Limer, and Hausman. First, in order to choose the type of model estimates, it is necessary to test the F Limer and Hausman. In second, we estimated both RE model and FE model.

We have also employed FE and RE models to test the robustness of estimated results. To compare the FE with RE, Hausman test is employed. The value of Hausman test is significant which shows that FE is a better choice for the analysis as compared to RE. The results of FE and RE models are steady with pooled OLS results, which circumstantiate the existence of relationship between FDI, EF and growth. Additionally, positive we first estimate the model with the whole index of EF and the results are showed in Table 3. 
Table 3. Panel Regression results

\begin{tabular}{|c|c|c|c|c|c|c|}
\hline & FE & $\mathbf{R E}$ & FE & $\mathbf{R E}$ & FE & RE \\
\hline \multirow[t]{2}{*}{ Constant } & 4.68 & 4.70 & 6.70 & 6.72 & 6.26 & 6.26 \\
\hline & $(6.70)^{*}$ & $(3.85)^{* *}$ & $(18.74)^{*}$ & $(5.92)^{* *}$ & $(32.22)^{*}$ & $(5.28)^{* *}$ \\
\hline \multirow[t]{2}{*}{$\mathbf{E F}$} & 1.98 & 2.11 & 1.92 & 2.07 & 2.18 & 2.25 \\
\hline & $(2.72)^{*}$ & $(2.89)^{*}$ & $(2.64)^{*}$ & $(2.67)^{* *}$ & $(3.24)^{*}$ & $(3.47)^{*}$ \\
\hline \multirow[t]{2}{*}{ FDI } & 0.29 & 0.35 & 0.28 & 0.38 & 0.32 & 0.40 \\
\hline & $(1.59)^{*}$ & $(1.92)^{* *}$ & $(1.43)^{*}$ & $(2.09)^{* *}$ & $(1.82)^{*}$ & $(2.21)^{*}$ \\
\hline \multirow[t]{2}{*}{ EF1 } & & & -0.82 & -0.66 & -0.52 & -0.38 \\
\hline & & & $(-3.36)^{*}$ & $(-2.64)^{*}$ & $(-1.65)^{*}$ & $(-1.02)^{*}$ \\
\hline \multirow[t]{2}{*}{ EF2 } & & & 1.78 & 1.52 & 1.41 & 0.95 \\
\hline & & & $(4.86)^{*}$ & $(4.31)^{*}$ & $(3.90)^{* *}$ & $(2.52)^{* *}$ \\
\hline \multirow[t]{2}{*}{ EF3 } & & & 1.19 & 0.97 & 0.78 & 0.73 \\
\hline & & & $(3.83)^{*}$ & $(3.16)^{*}$ & $(2.07)^{*}$ & $(2.02)^{*}$ \\
\hline \multirow[t]{2}{*}{ EF4 } & & & 1.62 & 1.46 & 1.42 & 1.24 \\
\hline & & & $(4.03)^{* *}$ & $(4.16)^{* *}$ & $(4.07)^{* *}$ & $(3.28)^{* *}$ \\
\hline \multirow[t]{2}{*}{ EF5 } & & & 1.72 & 1.65 & 1.76 & 1.58 \\
\hline & & & $(4.55)^{*}$ & $(4.64)^{*}$ & $(4.47)^{*}$ & $(4.12)^{*}$ \\
\hline \multirow[t]{2}{*}{ TROPEN } & & & & & 0.47 & 0.46 \\
\hline & & & & & $(4.05)^{*}$ & $(4.04)^{*}$ \\
\hline \multirow[t]{2}{*}{ INF } & & & & & 1.63 & 1.86 \\
\hline & & & & & $(3.49)^{* * *}$ & $(3.62)^{* * *}$ \\
\hline \multirow[t]{2}{*}{ GCF } & & & & & 0.36 & 0.42 \\
\hline & & & & & $(3.76)^{*}$ & $(3.95)^{*}$ \\
\hline \multirow[t]{2}{*}{ FINDEP } & & & & & 1.84 & 1.96 \\
\hline & & & & & $(7.21)^{*}$ & $(7.42)^{*}$ \\
\hline \multirow[t]{2}{*}{ Wald Chi-sq } & & 10.60 & & 9.97 & & 13.22 \\
\hline & & 0.0076 & & 0.0421 & & 0.0287 \\
\hline \multirow[t]{2}{*}{ F statistic } & 553.10 & & 551.13 & & 566.09 & \\
\hline & 0.0000 & & 0.0000 & & 0.0000 & \\
\hline Adjusted R $\mathbf{R}^{2}$ & 0.89 & 0.65 & 0.89 & 0.73 & 0.89 & 0.85 \\
\hline
\end{tabular}

Notes: $* * *, * * *$ indicates coefficient is significant at $1 \%, 5 \%$ and $10 \%$ level of significance respectively, Wald Chi-Square is used to assess the overall model fit for RE and F-statistic is used to test the overall model fit for FE, Numbers in parentheses are $t$ statistic.

Both the versions RE and FE show a very good whole model fit as remarked by the Wald Chi-Square and F-statistic respectively. In model 1, RE is better than FE and the equations, in the model 2 and model 3, FE is better than RE at level 5\%. It is clear that the EF is highly positively correlated with economic growth; coefficient is 1.98 and $\mathrm{t}$ statistic is 2.72, meaning that the coefficient is statistically significant at all levels. One unit increase in the EF leads to a $1.98 \%$ increases in growth; It is clear that the FDI is highly positively correlated with economic growth; coefficient is 0.29 and t statistic is 1.59 , meaning that the coefficient is statistically significant at all levels. One unit increase in the EF leads to a $0.29 \%$ increases in growth.

The second model is used to determine individually the impact of the constituents of EF on economic growth. EF1 is significant and the coefficient is negative, implying that a larger government size decreases growth. The estimated 
size suggests that one unit increase of the index decreases the average growth by roughly $0.82 \%$. Most previous studies have found a positive relation between this variable and growth. EF2 is significant and positive, and the estimated size suggests that one unit increase of the index increases growth by $1.78 \%$. This result is somewhat surprising since most previous studies have found a negative or not significant relation. Property rights are protected through strong and unbiased judicial system, establishment of impartial and strong judicial system may decrease the process of growth through sufficient provision of protection to property rights; EF3 is positive and significant, and one unit increase of the index increases growth by $1.19 \%$. EF4 is significant and interestingly there is a positive relation; freedom to trade increases growth. The result suggests that one unit increase of the index increases growth by $1.62 \%$. EF5 is positive and significant, and one unit increase of the index increases growth by $1.72 \%$.

We re-estimate regressions by including our supplement control variables. In the model 3 we include Trade Openness. Coefficient EF is positive and significant at the $1 \%$ level nonetheless, TROPEN has positive and significant, and one unit increase of the index increases growth by $0.47 \%$. In the model 3 we added Financial Development Indicator. Results present, coefficient FINDEP is positive and significant, and one unit increase of the index increases growth by $1.84 \%$. In the model 3 we include Infrastructure Quality; changes INF a country positively and significantly influence the growth with a coefficient of 1.63. In the model 3, we include Gross Capital Formation. Coefficient GCF is positive and significant, and one unit increase of the index increases growth by $0.36 \%$, additional coefficients EF and FDI is positive and significant at the $1 \%$ level. The value of $\mathrm{R}$ is 0.89 and F-statistic measures statistically significant. Coefficients FDI is positive and significant at $1 \%$ level and one unit increase in the FDI leads to a $0.35 \%$ increase in growth. Consequently, four of the significant EF variables are positively related to growth but one are negatively related.

\section{Conclusion}

Economically free institutions have an important role for taking advantage of opportunity to improve the life standards of citizens in the developing countries. The relationship between EF and economic growth has been discussed in economic literature. In order to test this relationship, most researchers used various measures of economic and social performance. We can say that the general comment obtained from the numerous articles is that $\mathrm{EF}$ is vitally important to a society. Moreover, EF induces less poverty and improvements in the life standards of citizens of a nation. It is worth noted that countries should focus not only on policies to attract FDI but also on the policies that are necessary for FDI to generate a positive development impact in the recipient country. When investigating the aggregate effect of the EF, we found that an increase in economic freedom, increases growth. Most of the previous studies, as emphasized in the literature review, have found a positive and robust relationship between $\mathrm{EF}, \mathrm{FDI}$ and economic growth, which supports the results of this research.

In this research, the relationship among EF, FDI and economic growth nexus in the BRICS countries over the period 1995-2013 was investigated. In order to estimate the relation, panel data estimation techniques were employed. We estimated both RE model and FE model. The results of the research will strengthened the view that FDI and EF to trade will continue to be viewed as two keys determinant of economic growth. The research found that the EF and FDI is have positive and significant effect on economic growth. We decompose the EF into the five categories constructing the index and we observed that just size of government are another key ingredient of EF that is negatively correlated with growth. Government size is negatively correlated with growth. Because increase in government size positively affects the better allocation of resources. Another index of EF is positively correlated to growth. This index may be developed, extended with new and better proxies and used in investigating the impact of EF on other macroeconomic magnitudes including investment, trade, even technology. In addition Trade Openness, Financial Development, Infrastructure Quality and Gross Capital Formation is have positive and significant effect on economic growth.

The empirical analysis has some policy implications towards the improvement of investment climate to attract higher FDI inflows into BRICS countries that are expected to facilitate their economy in enhancement of market potential, infrastructural development and capital formation. The tag of fast-paced economic growth notwithstanding, BRICS, will have to tackle the challenge of ensuring and achieving growth without sacrificing equity, and by utilizing the benefits of innovation to address the issues of inequality of economies. The challenge is to have an innovation policy that will ensure growth accompanied by equity, for which they must have necessary institutional mechanisms in place. Due to the immense economic power of the BRICS countries, they are becoming a political factor and thereby create a balance of forces within the international relations. That will, on hand, change the BRICS countries themselves, on the other hand, it changes the relations of the current leading forces, the USA and EU toward BRICS and it also changes the perspectives regarding the possibility of an economic boom. With these new constellations of 
the relations within the globalised world, it is expected that the leading countries in the world will start creating the new world order.

\section{References}

Ahmed, Y., \& Anoruo, E. (2000). Openness and Economic Growth: Evidence from Selected ASEAN Countries. The Indian Economic Journal, 47(3), 110-117.

Ahn, S. C., \& Moon, H. R. (2001). Large-N and Large-T Properties of Panel Data Estimators And the Hausman Test. USC CLEO Research Paper No. C01-20. http://dx.doi.org/10.2139/ssrn.283252

Ali, A., \& Crain, W. M. (2002). Institutional Distortions, Economic Freedom, and Growth. Cato Journal, 21(3), 415-426.

Ayal, E. B., \& Karras, G. (1998). Components of Economic Freedom and Growth: An Empirical Study. Journal of Developing Areas, 32, 327-338.

Azman-Saini, W. N., Baharumshah, A. Z., \& Law, S. H. (2010). Foreign Direct Investment, Economic Freedom and Economic Growth: International Evidence. Economic Modelling, 27(5), 1079-1089. http://dx.doi.org/10.1016/j.econmod.2010.04.001

Bengoa, M., \& Sanchez-Robles, B. (2003). Foreign Direct Investment, Economic Freedom and Growth: New Evidence from Latin America. European Journal of Political Economy, 19(3), 529-545. http://dx.doi.org/10.1016/s0176-2680(03)00011-9

Berggren, N. (2003). The Benefits of Economic Freedom: A Survey. The Independent Review, 8(2), 193-211.

Broadman, H. G., \& Recanatini, F. (2001). Where Does All the Foreign Direct Investment Go In Russia?. World Bank Policy Research Working Paper, World Bank, Washington DC.

Carlsson, F., \& Lundstrom, S. (2002). Economic Freedom and Growth: Decomposing the Effects. Public Choice, 112(3-4), 335-344. http://dx.doi.org/10.1023/a:1019968525415

Cebula, R. J. (2011). Economic Growth, Ten Forms of Economic Freedom, and Political Stability: An Empirical Study Using Panel Data, 2003-2007. The Journal of Private Enterprise, 26(2), 61-81.

Chang, S. C. (2010). Estimating Relationships among FDI Inflow, Domestic Capital, and Economic Growth Using the Threshold Error Correction Approach. Emerging Markets Finance \& Trade, 46(1), 6-15. http://dx.doi.org/10.2753/ree1540-496x460101

Chong, A., \& Calderon, C. (2000). Causality and Feedback between Institutional Measures And Economic Growth. Economics and Politics, 12(1), 69-81. http://dx.doi.org/10.1111/1468-0343.00069

Cole, J. H. (2003). The Contribution of Economic Freedom to World Economic Growth, 1980-99. Cato Journal, 23(2), 189-198.

Conklin, D. (2002). Analyzing and Managing Country Risks. Ivey Business Journal, 66(3), 17.

Dawson, J. W. (1998). Institutions, Investment, And Growth: New Cross-Country And Panel Data Evidence. Economic Inquiry, 36(4), 603-619. http://dx.doi.org/10.1111/j.1465-7295.1998.tb01739.x

Dawson, J. W. (2003). Causality in the Freedom-Growth Relationship. European Journal of Political Economy, 19(3), 479-495. http://dx.doi.org/10.1016/s0176-2680(03)00009-0

de Haan, J., \& Siermann, C. L. J. (1998). Further Evidence on the Relationship between Economic Freedom and Economic Growth. Public Choice, 95, 363-380.

de Haan, J., \& Sturm, J. E. (2000). On the Relationship between Economic Freedom and Economic Growth. European Journal of Political Economy, 16(2), 215-241. http://dx.doi.org/10.1016/s0176-2680(99)00065-8

de Mello, L. R. (1999). Foreign Direct Investment-Led Growth: Evidence from Time Series and Panel Data. Oxford Economic Papers 51(1), 133-151. http://dx.doi.org/10.1093/oep/51.1.133

Demetriades, P., \& Law, S. H. (2006). Finance, Institutions and Economic Development. International Journal of Finance and Economics, 11(3), 245-260. http://dx.doi.org/10.1002/ijfe.296

Dhakal, D., Mixon, F., \& Upadhyaya, K. (2007). Foreign Direct Investment and Transition Economies: Empirical Evidence from a Panel Data Estimator. Economics Bulletin, 6(3), 1-9. 
Dollar, D., \& Kraay, A. (2002). Growth is Good for the Poor. Journal of Economic Growth, 7, 195-225. http://dx.doi.org/10.1093/0199268657.003.0002.

Drabek, Z., \& Payne, W. (2002). The Impact of Transparency on Foreign Direct Investment. Journal of Economic Integration, 17(4), 777-810. http://dx.doi.org/10.11130/jei.2002.17.4.777

Fortanier, F. (2007). Foreign Direct Investment and Host Country Economic Growth: Does the Investor's Country of Origin Play a Role? Transnational Corporations, 16(2), 41-76.

Gray, H. P. (2000). Globalization and Economic Development. Global Economy Quarterly, 1, 71-96.

Gwartney, J. (2009). Institutions, Economic Freedom, and Cross-Country Differences in Performance. Southern Economic Journal, 75(4), 937-956.

Gwartney, J. D., Holcombe, R. A., \& Lawson, R. G. (2004). Economic Freedom, Institutional Quality and Cross-Country Differences in Income and Growth, Cato Journal, 24(3), 205-233.

Habib, M., \& Zurawicki, L. (2002). Corruption and Foreign Direct Investment, Journal of International Business Studies, 33(2), 291-307. http://dx.doi.org/10.1057/palgrave.jibs.8491017

Hanke, S. H., \& Walters, S. J. K. (1997). Economic Freedom, Prosperity, and Equality: A Survey. Cato Journal, 17(2), 117-146.

Harms, P., \& Ursprung, H. W. (2002). Do Civil And Political Repression Really Boost Foreign Direct Investment?. Economic Inquiry, 40(4), 651-663. http://dx.doi.org/10.1093/ei/40.4.651

Hausman, J. A. (1978). Specification Tests in Econometrics. Econometrica, 46(6), 1251-1271. http://dx.doi.org/10.2307/1913827

Heckelman, J. C. (2000). Economic Freedom and Economic Growth: A Short-Run Causal Investigation. Journal of Applied Economics, 3(1), 71-91.

Heckelman, J. C., \& Stroup, M. D. (2000). Which Economic Freedoms Contribute to Growth?. Kyklos, 53(4), 527-544. http://dx.doi.org/10.1111/1467-6435.00132

Im, K. S., Pesaran, M. H., \& Shin, Y. (2003). Testing for Unit Roots in Heterogeneous Panels. Journal of Econometrics, 115(1), 53-74. http://dx.doi.org/10.1016/s0304-4076(03)00092-7

Islam, S. (1996). Economic Freedom, Per Capita Income and Economic Growth. Applied Economics Letters, 3(9), 595-597. http://dx.doi.org/10.1080/135048596356032

Jadhav, P. (2012). Determinants of Foreign Direct Investments in BRICS Economies: Analysis of Economic, Institutional and Political Factors. Procedia-Social and Behavioral Sciences, 37, 5-14. http://dx.doi.org/10.1016/j.sbspro.2012.03.270

Jadhav, P., \& Katti, V. (2012). Institutional and Political Determinants of Foreign Direct Investment: Evidence from BRICS Economies. Poverty \& Public Policy, 4(3), 49-57. http://dx.doi.org/10.1002/pop4.5

Janicki, H. P., \& Wunnava, P. V. (2004). Determinants of Foreign Direct Investment: Empirical Evidence From EU Accession Candidates. Applied Economics, 36(5), 505-509. http://dx.doi.org/10.1080/00036840410001682214

Johnson, A. (2006). The Effects of FDI Inflows on Host Country Economic Growth. Working Paper no. 58, Centre of Excellence for Science and Innovation Studies, Stockholm.

Justesen, M. K. (2008). A Study of the Causality between Income and Economic Freedom. European Journal of Political Economy, 24(3), 642-660.

Kapuria-Foreman, V. (2007). Economic Freedom and Foreign Direct Investment in Developing Countries. The Journal of Developing Areas, 41(1), 143-154. http://dx.doi.org/10.1353/jda.2008.0024

Knack, S., \& Keefer, P. (1995). Institutions and Economic Performance: Cross-Country Tests Using Alternative $\begin{array}{lllll}\text { Institutional } & \text { Measures. }\end{array}$ http://dx.doi.org/10.1111/j.1468-0343.1995.tb00111.x

Kyrkilis, D., \& Pantelidis, P. (2003). Macroeconomic Determinants of Outward Foreign Direct Investment, International Journal of Social Economics, 30(7), 827-836. http://dx.doi.org/10.1108/03068290310478766

Levin, A., Lin, C. F., \& Chu, C. J. (2002). Unit Root Tests in Panel Data: Asymptotic and Finite-Sample Properties. Journal of Econometrics, 108(1), 1-24. http://dx.doi.org/10.1016/s0304-4076(01)00098-7 
Mahmood, K., Azid, T., Chaudhry, I. S., \& Faridi, M. Z. (2010). Impact of Economic Freedom on Economic Growth: The Case of Some Selected SAARC Member Countries. International Research Journal of Finance and Economics, 52, 7-16.

Mauro, P. (1995). Corruption and Growth. Quarterly Journal of Economics, 110(3), 681-712. http://dx.doi.org/10.2307/2946696

North, D. C. (1990). Institutions, Institutional Change, and Economic Performance. New York: Cambridge University Press. http://dx.doi.org/10.1017/cbo9780511808678.014.

O’Neill, J., Wilson, A., Purushothaman, V., \& Stupnytska, N. (2005). How Solid Are The Brics?. Goldman Sachs Economic Research, (134).

Pearson, D., Nyonna D., \& Kim, K. J. (2012). The Relationship between Economic Freedom, State Growth and Foreign Direct Investment in US States. International Journal of Economics and Finance, 4(10), 140-146. http://dx.doi.org/10.5539/ijef.v4n10p140

Pradhan, R. P. (2009). The FDI-Led-Growth Hypothesis in ASEAN-5 Countries: Evidence from Co Integrated Panel Analysis. International Journal Business and Management, 4(12), 153-164.

Ray, E. J. (1989). The Determinants of Foreign Direct Investment in the United States, 1979-85. In Robert C. Feenstra (Ed.), Trade Policies for International Competitiveness (pp. 53-84). University of Chicago Press.

Rodrik, D., Subramanian, A., \& Trebbi, F. (2004). Institutions Rule: The Primacy of Institutions over Geography and Integration In Economic Development. Journal of Economic Growth, 9(2), 131-165. http://dx.doi.org/10.1023/b:joeg.0000031425.72248.85

Romalis, J. (2007). NAFTA's and CUSFTA's Impact on International Trade. Review of Economics and Statistics, 89(3), 416-435. http://dx.doi.org/10.1162/rest.89.3.416

Tiwari, A. K. (2011). Foreign Aid, Fdi, Economic Freedom and Economic Growth in Asian Countries. Global Economy Journal, 11(3), 1-26. http://dx.doi.org/10.2202/1524-5861.1705

van Agtamael, A. (2012). Statele BRICS. Foreign Policy, 11, 62-65.

Vega-Gordillo, M., \& Álvarez-Arce, J. L. (2003). Economic Growth and Freedom: A Causality Study. Cato Journal, 23(2), 199-215.

Vijayakumar, N., Sridharan, P., \& Rao, K. C. (2010). Determinants of FDI in BRICS Countries: A Panel Analysis. International Journal of Business Science and Applied Management, 5(3), 1-13.

Voyer, P. A., \& Beamish, P. W. (2004). The Effect of Corruption on Japanese Foreign Direct Investment. Journal of Business Ethics, 50(3), 211-224. http://dx.doi.org/10.1023/b:busi.0000024737.57926.bf

Zafar, A. (2013). The Determinants of Inward FDI in BRICS Countries: Evidence from a Time Series Data Analysis. Journal of Economics and Sustainable Development, 4(5). 